\title{
Ceramics Vitreous China Produced by Utilizing Sediment Soil from Water Supply Treatment Process
}

\author{
Ubolrat Wangrakdiskul , Jindakarn Wanasbodee and Pornnapa Sansroi \\ 1518 Production Engineering Department, Faculty of Engineering, King Mongkut's University of Technology North Bangkok, Thailand
}

\begin{abstract}
Due to generating the abundant of sediment soil, it makes the high burden of disposal cost to the metropolitan waterworks authority. Enhancing the value of sediment soil has been explored. This research aims to utilize the sediment soil, wastes of water supply treatment process for producing ceramics vitreous china. In this experiment, five types of raw materials are exploited, namely, sediment soil, ball clay, kaolin, feldspar and silica sand. The formulas have been divided into two groups. Sediment soil has been used as substituted material in ball clay for the first group, and substituted in kaolin for the second group. The specimens of each formula are formed by uniaxial pressing at 100 bar of size $50 \times 100 \times 7 \mathrm{~mm}$. Then they have been sintered at two different temperatures, $1200^{\circ} \mathrm{C}$ and $1250^{\circ} \mathrm{C}$, with heating rate $400^{\circ} \mathrm{C} / \mathrm{hr}$ and soaking for 30 minutes. The result reveals that the suitable formula for ceramics vitreous china is No. 244 of Group 2 with sintering temperature $1250^{\circ} \mathrm{C}$. Its mixture consists of $0 \%$ kaolin, $35 \%$ ball clay, $30 \%$ feldspar, $20 \%$ silica sand and $15 \%$ sediment soil. The properties of this formula are $9.4 \%$ shrinkage, $9.39 \mathrm{MPa}$ of bending strength, $6.34 \times 10^{-6} / \mathrm{K}$ coefficient of thermal expansion, and $0.66 \%$ water absorption.
\end{abstract}

\section{Introduction}

Metropolitan Waterworks Authority (MWA) is one of an important state enterprises providing water supply for supporting people in the metropolitan area. With the growing population as well as the change in people's living behaviors nowadays, the demand of water consumption is increasing. Therefore, four main plants of water supply have been constructed for serving the increased demand.

These plants are located at Bangkhaen, Mahasawat, Samsen, and Thonburi area with the capacities 3.6, 0.8, $0.7,0.17$ million cubic meter/day. In addition to producing the quality water, sediment Soil has been generated from the water supply treatment process at the clarification station. They have been considered as wastes of the process and generated more than 0.1 million ton/year. Eliminating these sediment soil lead the high disposal costs to the MWA approximately $2 \times 10^{6} \mathrm{THB} /$ year.

As mentioned above, the problem has been studied and solved by many researchers. Suriyachat et al have reported the application sediment soil from water supply for ceramics products of the SME industry. The research found that ratio of sediment Soil: sand at 70:30 can be used for producing ceramic ware sintered at $800^{\circ}-900^{\circ} \mathrm{C}$ [1]. The properties of lighted weight concrete using sediment soil from water supply process as coarse aggregate have been examined by Boonin et al. The results showed that compressive strength of concrete with the ratio 80:20 of plastic clay: sediment soil can achieve the ASTM C338 [2]. Chatsatapattayakul et al have used the chemical sludge from water treatment system with cement in cement mortar and soil cement block. They summarized that soil cement block mixing with $10-30 \%$ of chemical sludge met the standards of the Thailand Institute of Scientific and Technological Research (TISTR) for attending a good strength and water resistance [3]. Apart from utilizing sediment soil from water supply treatment process, the similar wastes of the water treatment process from the different sources have been studied. Teixeira et al showed that up to $20 \%$ sludge of water treatment plant (silt, sand and clay) can be incorporated into clays used for producing ce ramic bricks [4]. Martínez-García et al have assessed the effect of incorporating waste sludge on the properties and microstructure of clay used for bricks manufacturing. Replacing clay in a ceramic body with different proportions of sludge can reduce the cost due to the utilization of waste. Results have shown that incorporating up to $5 \mathrm{wt} \%$ of sludge is beneficial for clay bricks [5]. Investigation utilizing fresh water treatment sludge (WTS) on the physical and mechanical properties, structural parameters as well as mineralogical composition of the ceramic products has been examined by Kizinievic et al. It was found that WTS additive, which is mostly composed from colorific $\mathrm{Fe}_{2} \mathrm{O}_{3}$, can be utilized as a natural pigment that dyes the ceramic body in darker, more intense red color [6]. Moreover, industrial solid waste generated by a water treatment plant (WTP) at a pulp mill was used for manufacturing construction fired bricks. Wolff et al have proposed that sludge can be 
used as a substitute for clay in the formulation of clay masses and the mixtures between $50-85 \%$ at 850 and $950^{\circ}$ $\mathrm{C}$ should be tested in the ceramic industry on a pilot scale in order to evaluate their suitability for the production of interior coatings or acoustic bricks [7].

However, the previous researches have not been studied the utilizing of sediment soil for ceramic vitreous china, which can be produced the sanitary ware, table ware, etc. Vitreous china has water absorption less than $1 \%$ with coefficient of thermal expansion $4-6 \times 10^{-6} / \mathrm{K}[8]$. Therefore, this research has focused on studying the effect of sediment soil from water supply treatment process for producing ceramic vitreous china. The benefit of this study can promote the eco-friendly products which utilizing industrial wastes.

Table 1. Chemical analysis of raw materials

\begin{tabular}{|c|c|c|c|c|c|}
\hline \multirow{2}{*}{ \% Oxide } & \multicolumn{5}{|c|}{ Raw Materials } \\
\cline { 2 - 6 } & $\begin{array}{c}\text { Maetan } \\
\text { Ball Clay }\end{array}$ & $\begin{array}{c}\text { Ranong } \\
\text { Kaolin Clay }\end{array}$ & $\begin{array}{c}\text { Rayong } \\
\text { Silica Sand }\end{array}$ & $\begin{array}{c}\text { India } \\
\text { Potash } \\
\text { Feldspar }\end{array}$ & $\begin{array}{c}\text { Sediment } \\
\text { Soil }\end{array}$ \\
\hline $\mathrm{SiO}_{2}$ & 65.88 & 45.5 & 99.16 & 65.17 & 58.15 \\
\hline $\mathrm{Al}_{2} \mathrm{O}_{3}$ & 20 & 38 & - & 18.45 & 27.84 \\
\hline $\mathrm{Fe}_{2} \mathrm{O}_{3}$ & 1.37 & 0.8 & - & 0.17 & 7.17 \\
\hline $\mathrm{TiO}_{2}$ & 0.53 & 0.03 & 0.03 & 0.01 & 0.86 \\
\hline $\mathrm{CaO}$ & 0.22 & 0.01 & 0.03 & 0.22 & 0.94 \\
\hline $\mathrm{MgO}$ & 0.48 & 0.01 & 0.02 & 0.01 & 1.37 \\
\hline $\mathrm{K}_{2} \mathrm{O}$ & 1.86 & 0.9 & 0.04 & 12.73 & 2.76 \\
\hline $\mathrm{Na}_{2} \mathrm{O}$ & 0.21 & 0.01 & 0.09 & 3.11 & 0.14 \\
\hline $\mathrm{LOI}$ & 9.42 & 13 & 0.16 & 0.13 & 0.77 \\
\hline
\end{tabular}

Table 2. Mixture composition of replacement sediment soil in maetan ball clay and ranong kaolin clay

\begin{tabular}{|c|c|c|c|c|c|c|c|c|c|}
\hline \multirow{3}{*}{$\begin{array}{c}\text { Raw } \\
\text { Materials }\end{array}$} & \multicolumn{9}{|c|}{$\%$ Mixture } \\
\hline & \multicolumn{5}{|c|}{$\begin{array}{l}\text { Group 1.Replacement in } \\
\text { Maetan Ball Clay }\end{array}$} & \multicolumn{4}{|c|}{$\begin{array}{l}\text { Group 2. Replacement } \\
\text { in Ranong Kaolin Clay }\end{array}$} \\
\hline & No. & No. & $\begin{array}{l}\text { No. } \\
1 \_3\end{array}$ & $\begin{array}{l}\text { No. } \\
1 \_4\end{array}$ & No. & $\begin{array}{l}\text { No. } \\
2 \_1\end{array}$ & $\begin{array}{l}\text { No. } \\
2 \_2\end{array}$ & $\begin{array}{l}\text { No. } \\
2 \_3\end{array}$ & $\begin{array}{l}\text { No. } \\
2 \_4\end{array}$ \\
\hline $\begin{array}{l}\text { Ranong } \\
\text { Kaolin } \\
\text { Clay }\end{array}$ & 15 & 15 & 15 & 15 & 15 & 15 & 10 & 5 & 0 \\
\hline $\begin{array}{l}\text { Maetan } \\
\text { Ball Clay }\end{array}$ & 35 & 30 & 25 & 20 & 15 & 35 & 35 & 35 & 35 \\
\hline $\begin{array}{l}\text { India } \\
\text { Potash } \\
\text { Feldspar } \\
\end{array}$ & 30 & 30 & 30 & 30 & 30 & 30 & 30 & 30 & 30 \\
\hline $\begin{array}{l}\text { Rayong } \\
\text { Silica } \\
\text { Sand } \\
\end{array}$ & 20 & 20 & 20 & 20 & 20 & 20 & 20 & 20 & 20 \\
\hline $\begin{array}{l}\text { Sediment } \\
\text { Soil }\end{array}$ & 0 & 5 & 10 & 15 & 20 & 0 & 5 & 10 & 15 \\
\hline
\end{tabular}

Note that : No 1_1= No 2_1

\section{Materials and methods}

\subsection{Materials}

In this experiment, five types of raw materials are exploited, namely, sediment soil, ball clay, kaolin, feldspar, and silica sand. Wastes material; sediment Soil from water supply treatment process has been utilized for replacement on basic materials. Sediment Soil used in this study has been generated from Mahasawat Plant. The chemical analysis of all materials has been represented in Table 1 .
Notice that, all materials are local materials except India Potash Feldspar. The mixture of basic formula has been provided from Ubolrat and Vipa [9]. Considering chemical composition of sediment soil in Table 1, it indicates that main compositions are $\mathrm{SiO} 2$ and $\mathrm{Al} 2 \mathrm{O} 3$ which similar to Maetan ball clay and Ranong clay. Therefore, the mixture of this experiment has been classified into two groups. Firstly, it is to replace sediment soil in Maetan ball clay. And secondly, sediment soil has been used as replacement material in Ranong kaolin clay. All of formulas have been represented in Table 2. It consists of 8 formulas which No.1_1 is the basic formula.

\subsection{Methods}

All of materials as mentioned above have been prepared as the procedure illustrated in Fig. 1. It consists of 9 steps. In the 3rd step, formulas of varying the proportion of materials have been constructed which consist of 8 formulas as mentioned in Table 2 .

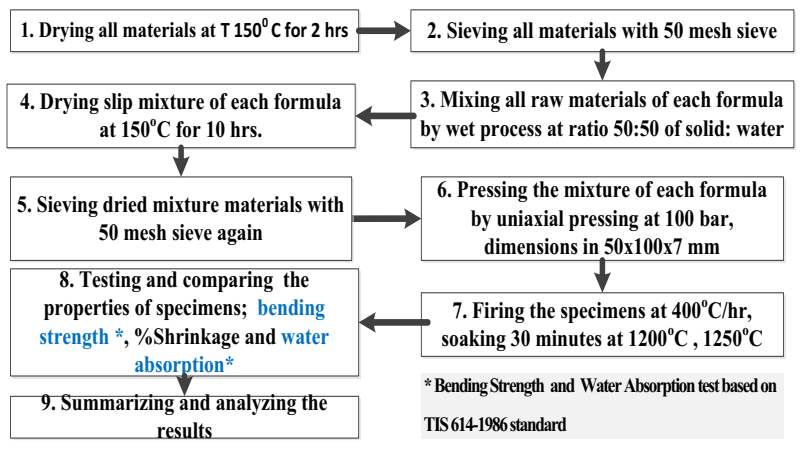

Figure 1. The 9 steps of this experiment.

\section{Results and discussion}

Specimens of each formula have been tested for analyzing the properties; bending strength, \%water absorption, and \%shrinkage. They can be described as follows.

\subsection{Mechanical and physical properties}

Three points bending has been used for testing bending strength of materials. All specimens of two material groups have been represented with their bending strength in Fig. 2 and Fig. 3. Increasing the ratio of sediment soil in the basic formula (No.1_1 or 2_1), the bending strength of them has gradually increased. Similarly, higher sintering temperature also increases the bending strength.

According to Fig. 4 and Fig. 5, both of two material groups have increased shrinkage when adding sediment soil in the basic formula. At the same time, sintering temperature increased also increase \%shrinkage of all specimens.

On the contrary, water absorption property is decreased when increasing the ratio of sediment soil in the basic formula (No.1_1 or No.2_1). In addition, 
increasing sintering temperature also decreases the water absorption of both two formula groups. These have been represented in Fig. 6 and Fig.7.

The results indicated that water absorption can be related to the shrinkage property, with higher shrinkage can provide lower water absorption. Furthermore, lower water absorption can promote the higher bending strength of specimens. These can be summarized that sediment soil has the potential to enhance the beding strength of vitreous china ceramics when comparing with using kaolin clay and ball clay.

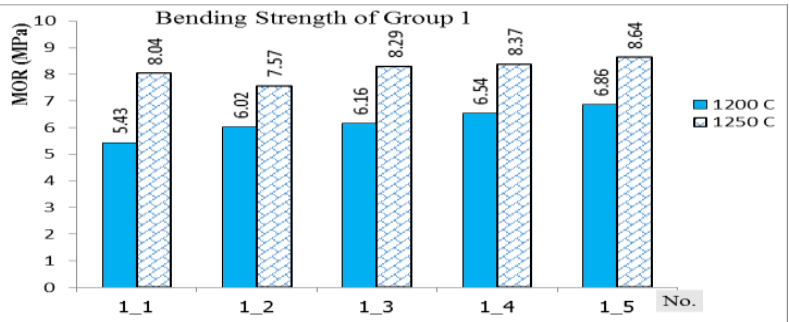

Figure 2. Bending strength of Group 1 at $1200^{\circ} \mathrm{C}, 1250^{\circ} \mathrm{C}$

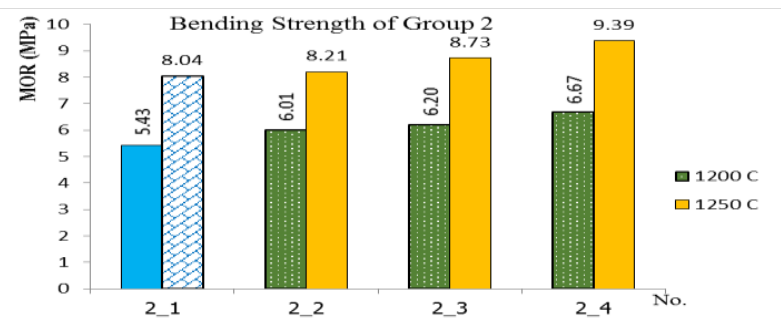

Figure 3. Bending strength of Group 2 at $1200^{\circ} \mathrm{C}, 1250^{\circ} \mathrm{C}$

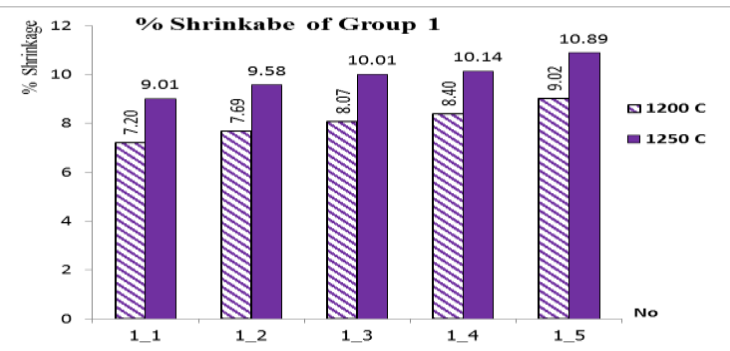

Figure 4. \%Shrinkage of Group 1 at $1200^{\circ} \mathrm{C}, 1250^{\circ} \mathrm{C}$

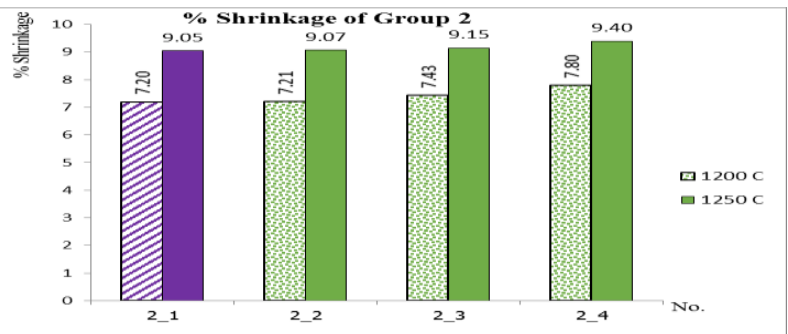

Figure $5 \%$ Shrinkage of Group 2 at $1200^{\circ} \mathrm{C}, 1250^{\circ} \mathrm{C}$

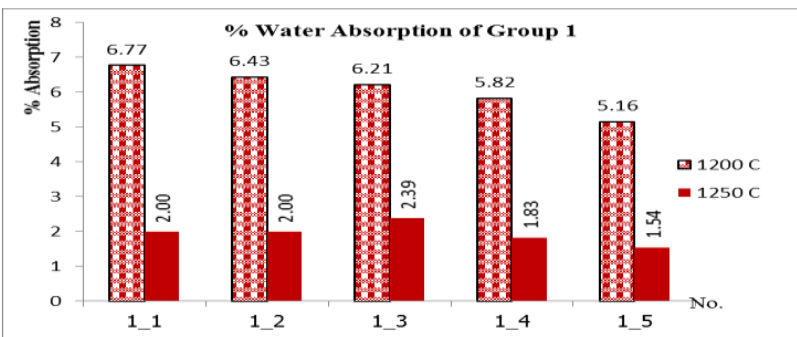

Figure. $6 \%$ Water absorption of Group 1 at $1200^{\circ} \mathrm{C}, 1250^{\circ} \mathrm{C}$

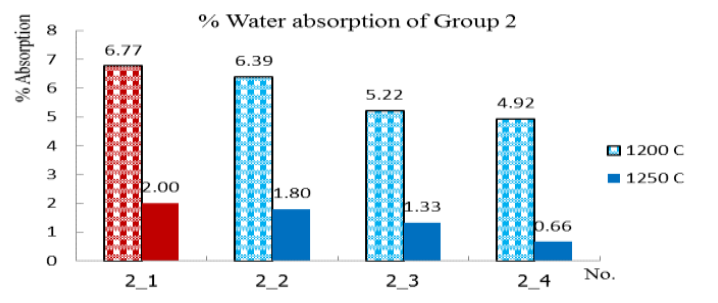

Figure 7. \%Water absorption of Group 2 at $1200^{\circ} \mathrm{C}, 1250^{\circ} \mathrm{C}$

\subsection{Statistical analysis}

For approving the results of this study, the experimental design has been conducted [10]. Two way ANOVA has been employed for analyzing the effect of raw material replacement on the properties of each formula. P-values of hypothesis testing with a 0.05 significance level of the experiment are illustrated in Table 3

As considering Table 3, formula and temperature refer to factors of mixture number and sintering temperature. Their $\mathrm{p}$ values are less than 0.05 , it means that formula number and temperature have the effects on bending strength, \% shrinkage and $\%$ water absorption.

Table 3 Two way ANOVA test for 2 factors effect on bending strength, \%Shrinkage, and \% Water Absorption

\begin{tabular}{|l|c|c|c|c|}
\hline \multirow{2}{*}{ P value } & \multicolumn{2}{|c|}{ Group 1 } & \multicolumn{2}{c|}{ Group 2 } \\
\cline { 2 - 5 } & Formula & Temp & Formula & Temp \\
\hline $\begin{array}{l}\text { Bending } \\
\text { Strength }\end{array}$ & 0.012 & 0 & 0.003 & 0 \\
\hline \%Shrinkage & 0 & 0 & 0.015 & 0 \\
\hline $\begin{array}{l}\text { \%Water } \\
\text { absorption }\end{array}$ & 0 & 0 & 0 & 0 \\
\hline
\end{tabular}

\begin{tabular}{|lccccc|}
\hline Two-way & ANOVA: MOR versus Formula, Temp \\
Source & DF & SS & MS & F & P \\
Formula & 4 & 10.439 & 2.6097 & 3.39 & 0.012 \\
Temp & 1 & 73.803 & 73.8028 & 96.00 & 0.000 \\
Interaction & 4 & 2.713 & 0.6782 & 0.88 & 0.478 \\
Error & 90 & 69.189 & 0.7688 & & \\
Total & 99 & 156.143 & & & \\
S $=0.8768$ & $\mathrm{R}-\mathrm{Sq}=55.69 \%$ & $\mathrm{R}-\mathrm{Sq}(\mathrm{adj})=51.26 \%$ \\
\hline
\end{tabular}

Figure 8. Probability plot of bending strength of Group 1

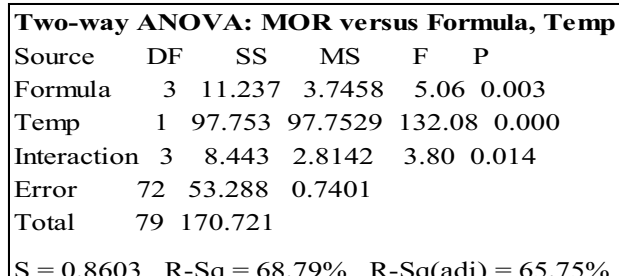

Figure 9. Probability plot of bending strength of Group 2

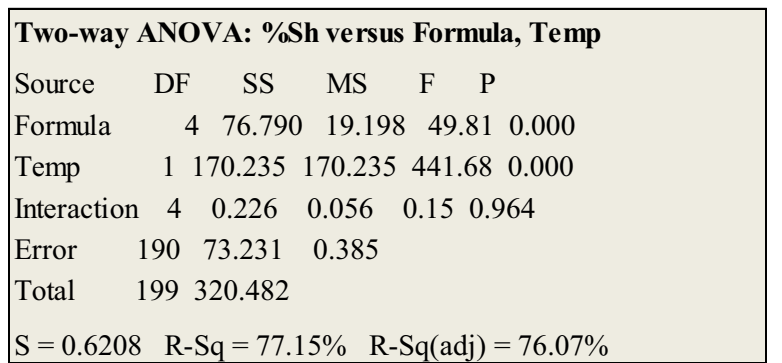

Figure 10. Probability Plot of Shrinkage of Group 1 
Details of $\mathrm{p}$ value of determined properties for two groups and different temperature have been represented in Fig. 8-9, Fig. 10-11, and Fig. 12-13.

\begin{tabular}{|c|}
\hline Two-way ANOVA: \%Sh versus Formula, Temp \\
\hline DF $\quad$ SS $\quad$ MS $\quad F \quad P$ \\
\hline $\begin{array}{llllll}\text { Formula } & 3 & 2.2457 & 0.7486 & 3.78 & 0.015\end{array}$ \\
\hline Temp $\quad 1 \quad 45.1144 \quad 45.1144 \quad 227.81 \quad 0.000$ \\
\hline 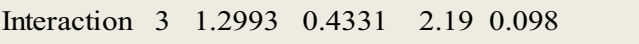 \\
\hline Error $\quad \begin{array}{llll}64 & 12.6740 & 0.1980\end{array}$ \\
\hline 7161.3334 \\
\hline $\mathrm{S}=0.4450 \quad \mathrm{R}-\mathrm{Sq}=79.34 \% \quad \mathrm{R}-\mathrm{Sq}(\mathrm{adj})=77.08 \%$ \\
\hline
\end{tabular}

Figure 11. Probability plot of shrinkage of Group 2

\begin{tabular}{|lccccc|}
\hline Two-way & ANOVA: $\% A b$ & versus Formula, Temp \\
Source & DF & SS & MS & F & P \\
Formula & 4 & 92.319 & 23.080 & 37.66 & 0.000 \\
Temp & 1 & 277.517 & 277.517 & 452.82 & 0.000 \\
Interaction & 4 & 72.502 & 18.125 & 29.57 & 0.000 \\
Error & 90 & 55.158 & 0.613 & & \\
Total & 99 & 497.496 & & & \\
S $=0.7829$ & $\mathrm{R}-\mathrm{Sq}=88.91 \%$ & $\mathrm{R}-\mathrm{Sq}(\mathrm{adj})=87.80 \%$ \\
\hline
\end{tabular}

Figure 12. Probability plot of absorption of Group 1

\begin{tabular}{|lccccc}
\hline Two-way & ANOVA: \%Ab versus & Formula,Temp \\
Source & DF & SS & MS & F & P \\
Temp & 1 & 383.472 & 383.472 & 437.17 & 0.000 \\
Formula & 3 & 32.327 & 10.776 & 12.28 & 0.000 \\
Interaction & 3 & 2.283 & 0.761 & 0.87 & 0.462 \\
Error & 72 & 63.156 & 0.877 & & \\
Total & 79 & 481.238 & & & \\
S $=0.9366$ & R-Sq $=86.88 \%$ & R-Sq(adj) $=85.60 \%$ \\
\hline
\end{tabular}

Figure 13. Probability plot of absorption of Group 2

\section{Conclusion}

The chemical composition of sediment soil as shown in Table 1 indicates that its main composition is $\mathrm{SiO}_{2}$ and $\mathrm{Al}_{2} \mathrm{O}_{3}$. However, it also contains the fluxing agents, namely, $\mathrm{K}_{2} \mathrm{O}, \mathrm{CaO}, \mathrm{Na}_{2} \mathrm{O}$ which are $2.76 \%, 0.94 \%$, $0.14 \%$. They take into account for reducing porosity and increasing bending strength of test pieces. Therefore, water absorption and bending strength have showed reducing and increasing of water absorption and bending strength, in Fig. 2,3 and 6,7. Due to reducing porosity, \% shrinkage of specimens has been increased when increasing sediment soil, as shown in Fig. 4 and 5.

When recognition on different sintering temperature, it revealed that higher sintering temperature has promoted the higher bending strength, lower water absorption and higher shrinkage of the specimens.

Furthermore, different group of formula materials has given the slightly different properties of test pieces. The effect of replacement sediment soil in Ranong Kaolin clay has promoted the higher bending strength and lower water absorption than replacing in Maethan ball clay. As the effect of Ranong kaolin clay's chemical analysis contains lower fluxing agent than Maethan ball clay and sediment soil.

Because water absorption of vitreous china is less than $1 \%$. The suitable formula of this study is No.2_ 4 sintering at $1250^{\circ} \mathrm{C}$, with less than $1 \%$ of water absorption. Its bending strength is higher than the others, which is $9.39 \mathrm{MPa}$ with coefficient of thermal expansion at $6.34 \times 10^{-6} / \mathrm{K}$ at $1000^{\circ} \mathrm{C}$. Mixture of this formula is $0 \%$ kaolin, 35\% ball clay, 30\% feldspar, 20\% silica sand and $15 \%$ sediment soil. It can be concluded that sediment soil can substitue ranong kaolin clay for producing vitreous china ceramics. This means that costs of material producing ceramic products has been decreased (Ranong kaolin clay: $6000 \mathrm{THB} /$ ton) . In addition, the burden of sediment soil diposal of MWA also has been alleviated (20 THB/ton).

However, the future work is to prepare the material for casting the vitreous china and extracting $\mathrm{Fe}_{2} \mathrm{O}_{3}$ should be performed. If the results of this study can be the commercial products, it may response the customer needs who favors the eco-friendly products.

\section{References}

1. D. Suriyachat, P. Vichitamornpun and W. Ruangsumret, Application of Sediment Soils, Metallurgical Technology Group, Bureau of Primary Industries, Department of Primary Industries and Mines, Country Report, Thailand (2004).

2. K. Boonin, S. Sarapol and S. Deesui. Properties of Lighted Weight Concrete used Sediment Soil from Water Supply Process as Coarse Aggregate, Department of Civil Engineering, Faculty of Engineering, Thesis, Khon Kaen University (2012).

3. N. Chatsatapattayakul, M. Wangwiang and P. Pengthamkeerati, Potential use of chemical sludge from water treatment system with cement in cement mortar and soil cement block, Rajabhat Journal of Science, Humanities \& Social Sciences. 13(1) 48-54 (2012)

4. S.R. Teixeira, G.T.A. Santos, A.E. Souza, P. Alessio, S.A. Souza and N.R. Souza, The effect of incorporation of a Brazilian water treatment plant sludge on the properties of ceramic materials, Applied Clay Science, 53, 561-565 (2011)

5. C. Martínez-García, D. Eliche-Quesada, L. PérezVillarejo, F.J. Iglesias-Godino and F.A. CorpasIglesias, Sludge valorization from wastewater treatment plant to its application on the ceramic industry, Journal of Environmental Management 95, S343-S348 (2012)

6. O. Kizinievic, R. Zurauskiene, V. Kizinievic and R. Zurauskas, Utilisation of sludge waste from water treatment for ceramic products, Construction and Building Materials, 41 ,464-473 (2013)

7. E. Wolff, W. Keller Schwabe and S. Vieira Conceiçao, Utilization of water treatment plant sludge in structural ceramics, Journal of Cleaner Production xxx, 1-8 (2014)

8. Silicate ceramics, Information on http://old.vscht.cz/sil/keramika/Ceramic_Technology /SM-Lect-6-A.pdf

9. U. Ounprasertpong and V. Kittidumkeng, Cullet glass as a flux, Material Department, Faculty of Science, Project, Chulalongkorn University (1984) 
10. M.J. Anderson, S.L. Kraber, Keys to successful designed experiments. Tech. Rep., Stat-Ease, Inc., Minneapolis, MN (2002). [Online]. Available: http://www.statease.com/pubs/doe-keys.pdf 